\title{
Exploration of the Profile and Intention in Restricting Online Game in Teenagers with Gaming Disorder: A Qualitative Study
}

\author{
Sitti Djannah ${ }^{1 *(\mathbb{D})}$ Fatwa Tentama $^{2}$ D, Rendi Sinanto ${ }^{1}$ D, Sulistyawati Sulistyawati ${ }^{4}$, Surahma \\ Asti Mulasari ${ }^{1} \mathbb{D}$, Tri Wahyuni Sukesi ${ }^{4} \mathbb{D}$, Rokhmayanti Rokhmayanti ${ }^{4}$ D, Siti Kurnia Widi Hastuti ${ }^{4}$, \\ Muhammad Syamsu Hidayat ${ }^{4}$, Ulinnuha Yudiansa Putra ${ }^{3}$ (D) \\ ${ }^{1}$ Department of Master in Public Health, Faculty of Public Health, Universitas Ahmad Dahlan, Yogyakarta, Indonesia; \\ ${ }^{2}$ Department of Master in Psychology, Faculty of Psychology, Universitas Ahmad Dahlan, Yogyakarta, Indonesia; ${ }^{3}$ Department \\ of Accounting, Faculty of Economic, Universitas Ahmad Dahlan, Yogyakarta, Indonesia; ${ }^{4}$ Department of Public Health, Faculty \\ of Public Health, Universitas Ahmad Dahlan, Yogyakarta, Indonesia
}

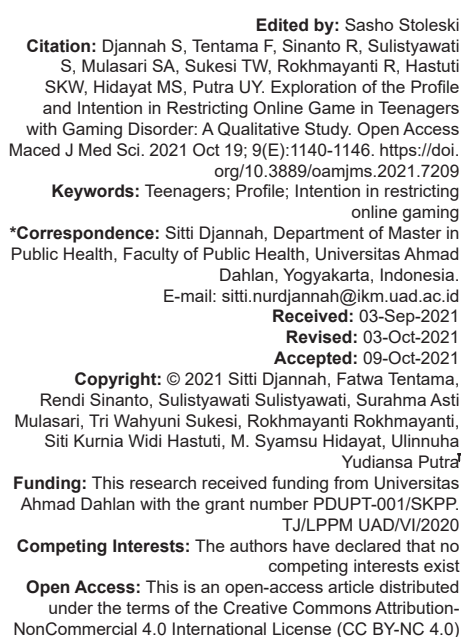

NonCommercial 4.0 International License (CC BY-NC 4.0)

\begin{abstract}
BACKGROUND: Gaming disorder is a kind of mental disorder that applies to people who spend most of their spare time playing games and people are addicted to playing online games. This condition is more common in adolescents and eventually could harm their health. Thus, the researchers are interested in studying teenagers' profiles and intentions to identify their efforts and obstacles in restricting the time spend playing online games.
\end{abstract}

AIM: This study aimed to explore the profile and addiction scales of teenagers with online gaming disorder and to identify their intentions, plans, and obstacles in reducing their addictions.

METHODS: The study employed qualitative research with a phenomenological approach. The research included six online gamer participants. The researchers selected the participants using a purposive sampling technique. According to the scale of gamine addition, the participants were game-addicted teenagers. The researchers collected the data with a guided interview and an observation list. They analyzed the data using phenomenological analysis.

RESULTS: The scale of addiction data showed that all informants were in a high category of addiction. This scale of addiction was in line with their profiles, which explained that they played games at least $5 \mathrm{~h}$ a day because they perceived playing games as an urgent activity to relieve stress or as entertainment. When they played online games, they held back hunger and skipped their meals even though they were hungry, and they also often held back urinating. Moreover, their active gaming at night caused them to sleep in the daytime. In addition, the data showed that four of the informants stated that they had some intentions and plans to reduce or quit playing, but they did not have specific plans. They had not followed up on their readiness and had not known when to act. Some obstacles also prevented them from forming intentions to reduce or stop playing online games.

CONCLUSION: The profiles of the teenagers with gaming disorders showed a high level of addiction. They played online games as stress-relieving entertainment. When playing, they often tolerated hunger and thirst, refrained from urinating, and did not sleep at night. There were some teenagers with gaming disorders who had no intention of reducing or stopping their playing. Meanwhile, others were willing to reduce or quit playing, but they did not have any alternative activities and did not know when they would stop playing online games. Friends' invitations to play games, the fun of playing games, problems of self-control/habits, the temptation of watching other gamers playing, boredom and the new trend of electronic game sports were the addictive teenagers' obstacles for controlling their online gaming.

\section{Introduction}

According to ICD-11, gaming disorder is the diagnosis for a person who has no control over their gaming habits for at least 12 months, prioritises gaming over other interests or activities, and continues playing the game regardless of its harmful effects [1]. A game is an activity that can entertain and make people happy [2]. With the current development of information technology, online games on the computer, PlayStation, and smartphones with Internet connections are in high demand, especially for young people [3]. Online games are interesting because the players can interact with other players from different places [4]. Playing online games continuously without control lead to the development of negative behaviors for players, such as losing track of time and becoming addicted or gaming disorder [5].

Gaming disorder is characterized by excessive gaming for long periods of time [6]. The World Health Organization has categorized gaming disorder as a mental disorder [7]. In Indonesia, approximately, 2.7 million gamers suffer from gaming disorder [8]. Based on observations on July 30, 2020 in a boarding house in Yogyakarta, Indonesia, the researchers found teenagers playing online games to meet their daily needs. They played the game during the daytime (morning to afternoon).

Similarly, the researchers found that teenagers play online games on their smartphones at traditional and modern cafes. When they played online games, 
they often neglected basic physical activities, such as eating, sleeping, and urinating [9]. The frequency of using smartphones to access online games has made teenagers stay awake at night. A previous research has stated that smartphone addiction shows poor sleeping quality, which means that online games also have the potential to adversely affect one's health [6], [10]. Sleep deprivation is a risk to an individual's health as it can cause a deficiency in hemoglobin. It can also lead to heart disease due to an overcompensation of the heart as a result of poor cardiac relaxation [11], [12].

Another previous study found that game addicts typically neglect drinking and sleeping, have poor health ratings, and are prone to suffering heart diseases [11], [13]. Hakim and Raj defined two categories of gaming impacts, namely positive and negative, and classified each impact in terms of its social, clinical, academic, economic, and religious relevance. However, it seems that the negative impacts outnumbered the positive ones [14]. Furthermore, additional health effects of game addiction include changes to eating and sleeping patterns that result in afflictions such as ulcers and anemia [15].

This research aims to explore the profiles of teenagers with gaming disorders and to identify their plans or intentions to quit playing or at least to reduce their online game habits. Because the Internet's constant development might rapidly increase online gaming disorders in society, there is a sense of urgency in this research and its findings. Thus, this study helps to provide information for the public and policymakers to increase awareness surrounding the health issues of the people with gaming disorder and to define the intervention targets.

\section{Methods}

\section{Research design}

A qualitative method with a phenomenological approach was used in this study to explore the profiles of adolescents with online gaming disorders. The method examined the individuals' age, gender, occupation, how long they've been playing games, the duration of their gaming, game functions, game habits, and physical conditions (such as blood pressure, pulse, conjunctiva, and urine color). We also sought to understand their intentions of stopping or restricting their online gaming.

\section{Research subject}

Purposive sampling was used to select informants in this study using inclusion criteria. In total, six informants were recruited in this study.

\section{Data collection method}

Qualitative data were collected by semistructured interviews. Questions in an open-ended format were asked with the aim of determining the level of gaming addiction, as well as understanding the point of view and opinions of the informants. The in-depth interview guide was first validated by experts before being utilized in the study. During the interview, measurements of blood pressure, pulse rate, conjunctiva, and urine color of the informants were taken by researchers who work as nurses.

\section{Data credibility}

Triangulation and checking between informants were carried out to guarantee the credibility of the data taken by the researchers. After each data collection, the researchers provide a summary of the data taken to ensure its truth and accuracy. Triangulation was also carried out to measure the gaming addiction scale, which followed the standard protocol provided by Lemmens et al. [4] and modified by Bai [16]. In this study, the neutral option was removed by the researchers to prevent respondents from being inclined to choose this option when filling out the scale.

\section{Data analysis}

The data were analyzed in several steps. First, the researcher checked the available data. Then, the phenomenological analysis was carried out by following the Creswell method [17], which consists of organizing data, reading, coding, developing themes, describing the data, connecting the theme, and interpreting the data.

\section{Ethical approvals}

This research received an Ethical Clearance from the Ethics Committee of Ahmad Dahlan University number: 012010055.

\section{Results}

\section{The informants' profile}

Table 1 outlines the profile of teenagers with gaming disorders. Their ages (23-24 years old) put them in the late teen/student category. Their physical health indicators such as blood pressure, pulse, conjunctiva, and urine color were normal. They had each been playing games for more than 1 year. Their gaming duration, which was more than $3 \mathrm{~h}$ per day, confirms the gaming disorder diagnosis. They perceived gaming as enjoyable entertainment, a stress reliever, and an 
Table 1: The Profile of Teenagers with Gaming Disorder

\begin{tabular}{|c|c|c|c|c|c|c|}
\hline Category & Informant 1 & Informant 2 & Informant 3 & Informant 4 & Informant 5 & Informant 6 \\
\hline Age & 23 years old & 23 years old & 24 years old & 24 years old & 24 years old & 24 years old \\
\hline Sex & Male & Male & Male & Male & Male & Male \\
\hline Occupation & Student & Student & Student & Student & Student & Student \\
\hline Blood Pressure & $120 / 70 \mathrm{mmHg}$ & $110 / 70 \mathrm{mmHg}$ & $110 / 80 \mathrm{mmHg}$ & $100 / 60 \mathrm{mmHg}$ & $110 / 80 \mathrm{mmHg}$ & $120 / 80 \mathrm{mmHg}$ \\
\hline Pulse & $85 \times / \min$ & $78 \times / \min$ & $80 \times / \min$ & $80 \times / \min$ & $82 \times / \min$ & $90 \times / \min$ \\
\hline Conjunctiva & Anemia & Anemia & Anemia & Anemia & Anemia & Anemia \\
\hline Urine color & Light yellow & Light yellow & Light yellow & Light yellow & Light yellow & Light yellow \\
\hline $\begin{array}{l}\text { Started playing } \\
\text { games }\end{array}$ & 5 years ago & 3 years ago & 3 years ago & 4 years ago & Last year & 5 years ago \\
\hline $\begin{array}{l}\text { Duration of } \\
\text { gaming }\end{array}$ & More than $5 \mathrm{~h}$ & $19 \mathrm{~h}$ & $5 \mathrm{~h}$ & $6 \mathrm{~h}$ & $5 \mathrm{~h}$ & More than $5 \mathrm{~h}$ \\
\hline $\begin{array}{l}\text { Purpose of } \\
\text { gaming }\end{array}$ & $\begin{array}{l}\text { Game is really } \\
\text { important, stress } \\
\text { reliever, relaxing }\end{array}$ & $\begin{array}{l}\text { Game is important, spare time } \\
\text { activity }\end{array}$ & $\begin{array}{l}\text { Entertaining, and feel } \\
\text { entertained }\end{array}$ & $\begin{array}{l}\text { Game is important, } \\
\text { as entertainment, } \\
\text { spare time activity }\end{array}$ & $\begin{array}{l}\text { Game is really important, } \\
\text { as entertainment, spare } \\
\text { time activity }\end{array}$ & $\begin{array}{l}\text { Game is really important, } \\
\text { spare time activity }\end{array}$ \\
\hline Gaming habits & $\begin{array}{l}\text { Playing games until } \\
\text { dawn; when he plays } \\
\text { the game, he often } \\
\text { feels dissatisfied, so } \\
\text { he can't stop playing; } \\
\text { he stays up late } \\
\text { every night; holds } \\
\text { back his hunger and } \\
\text { delays his meals } \\
\text { even though he feels } \\
\text { hungry while playing }\end{array}$ & $\begin{array}{l}\text { He feels useless if he doesn't play } \\
\text { the game; he feels he can use } \\
\text { his time well if he plays games; } \\
\text { always actively playing games at } \\
\text { night and sleeps in the daytime; } \\
\text { the most influencing factor why } \\
\text { he plays games is because he is } \\
\text { surrounded by gamers, too; he } \\
\text { delays meals even though he feels } \\
\text { hungry; he also plays and follows } \\
\text { the trending e-sports }\end{array}$ & $\begin{array}{l}\text { He plays longer than the game } \\
\text { time, doesn't want to stop } \\
\text { playing, and keeps playing } \\
\text { regardless of sore eyes; he } \\
\text { always delays urinating until } \\
\text { he finishes the game; he only } \\
\text { urinates when he really can't } \\
\text { hold it; he always plays at the } \\
\text { night, sleeps in the morning, } \\
\text { and wakes up in the afternoon. }\end{array}$ & $\begin{array}{l}\text { He always stays up } \\
\text { late to play games, } \\
\text { delays his meals } \\
\text { and urination when } \\
\text { playing the games; } \\
\text { he never pays } \\
\text { attention to the } \\
\text { time he takes on } \\
\text { gaming }\end{array}$ & $\begin{array}{l}\text { He always feels tempted } \\
\text { when he watches other } \\
\text { people playing games } \\
\text { and when he listens to } \\
\text { the sound of the games; } \\
\text { he cannot control himself } \\
\text { when playing games; he } \\
\text { stays up late at night and } \\
\text { always delays his meals } \\
\text { when playing }\end{array}$ & $\begin{array}{l}\text { He plays games in his } \\
\text { spare time and always } \\
\text { loses track of time; he } \\
\text { always stays up late at } \\
\text { night and delays his meals } \\
\text { and urination when playing; } \\
\text { game is like a daily need } \\
\text { and he thinks about it all } \\
\text { the time }\end{array}$ \\
\hline
\end{tabular}

activity to play in their spare time. They admitted to abstaining their meals while playing and said that they could not quit online games.

\section{The informants' addiction scale}

There were 40 items to measure seven criteria of the online game addiction scale. The seven criteria were salience, tolerance, mood modification, withdrawal, relapse, conflict, and the problem, with the options of one to four favorable options. The total score of the 40 questions categorizes the test-taker into the low, moderate, or high category. The researcher calculated the addiction scale using the Sturges formula:

$$
\mathrm{Cl}=\frac{\text { Range }}{\mathrm{C}}
$$

Notes:

Cl: Class of Interval

Range: The difference between the highest and the lowest data

C: The number of classes

$$
\begin{gathered}
C l=\frac{(40 \times 4)-(40 \times 1)}{3} \\
C I=\frac{160-40}{3}=40
\end{gathered}
$$

Categories:

$$
\begin{array}{ll}
\text { 1. } & \text { Low: scores } 40-80 \\
\text { 2. } & \text { Moderate: scores 81-120 } \\
\text { 3. High: scores 121-160. }
\end{array}
$$

Table 2 presents the results on the informants' addiction scale. As expected, $100 \%$ of the informants scored in the highest category on the online game addiction scale, which indicates that they are addicted to online games. Afterward, the researchers measured the informants' intentions to reduce their game addiction level.

Table 2: The informants' addiction scale

\begin{tabular}{llll}
\hline No. & Participant Code & Score & Category \\
\hline 1 & P1 & 143 & High \\
2 & P2 & 151 & High \\
3 & P3 & 146 & High \\
4 & P4 & 145 & High \\
5 & P5 & 150 & High \\
6 & P6 & 144 & High \\
\hline
\end{tabular}

The informants' intention to quit or restrict online gaming

Table 3 clarifies that four of the six teenagers with gaming disorder stated that they were willing to restrict the time spent playing online games even though they did not have fixed plans to do so and did not yet know when they would quit playing online games.

Meanwhile, the other two informants stated that they were not willing to quit online games. Conclusively, none of the teenagers with gaming disorder had intentions to restrict online games as they did not have any alternative activities to gaming such as a hobby or sport. Furthermore, they could not think of a time to quit online games.

\section{The obstacles in the restriction of online gaming intention}

Table 4 summarizes that the obstacles in restricting online gaming for the teenagers with gaming disorder were their friend's invitation to play, the irresistible fun of playing games, problems of selfcontrol or changing their habits, and the temptation of watching other people play games. These obstacles were reported by five of the six informants. Additional obstacles mentioned were boredom and the current trend of e-sports. 
Table 3: The distribution of the informants' intentions to reduce or quit online games

\begin{tabular}{|c|c|c|c|c|}
\hline \multirow[t]{4}{*}{ Informant } & \multicolumn{4}{|c|}{ The result of the interviews: Intention Questionnaire } \\
\hline & \multirow{3}{*}{$\begin{array}{l}\text { Readiness } \\
\text { Plan to reduce or quit online } \\
\text { games (maximally } 1 \mathrm{~h} \text { per day) Yes/No }\end{array}$} & \multirow{3}{*}{$\begin{array}{l}\text { Time } \\
\text { The amount of time to reduce or quit online } \\
\text { games (in hour per day/month) }\end{array}$} & \multicolumn{2}{|l|}{ Preparation } \\
\hline & & & \multicolumn{2}{|c|}{ Preparation to quit online games: (checklist) } \\
\hline & & & $\begin{array}{l}\text { Preparation: Set friendship } \\
\text { boundaries with gamers? (Yes/No) }\end{array}$ & $\begin{array}{l}\text { Preparation: Alternative activities to online } \\
\text { games (hobbies or sports)? (Done, not yet) }\end{array}$ \\
\hline 1 & No & - & Yes, still be friends & Not yet \\
\hline 2 & No & - & Yes, still be friends & Not yet \\
\hline 3 & Yes & Do not know. It's hard to decide. & Yes, still be friends & Not yet \\
\hline 4 & Yes & Not sure & Yes, still be friends & Not yet \\
\hline 5 & Yes & Don't know & Yes, still be friends & Not yet \\
\hline 6 & Yes & Not for now. Do not know when. & Yes, still be friends & Not yet \\
\hline
\end{tabular}

\section{Discussion}

The data showed that all informants suffered from game addiction and excessive gaming [18]. The previous study, which investigated six male informants, revealed that the scale of game addiction among male students was moderate (68.84\%) [19]. Similarly, a study by Chen et al. [20] suggested that online game was addictive for male teenagers and early adults. Other studies also discovered that males were prone to game addiction as much as $97 \%$ [21], and male-dominated online game players as much as $95 \%$ compared to female [22]. These data indicate that males experience more game addiction than females.

The age of all the informants was in the late teen category, as defined by the National Family Planning Coordinating Board [23]. According to data from Newzoo in 2017, the majority of gamers are millennials aged $21-35$ years [8]. A study by Yosephine and Lesmana [24] described a positive correlation between parenting style and online game addiction in late teenagers. Another study confirms that game addiction is mostly experienced by teenagers [25]. This study explains that late teenagers are more vulnerable to experiencing game addiction as they are still searching for their self-identity and are surrounded by people adapting to their own current development.

Playing online games is a hobby of adults as well as teenagers [8]. Informants 1, 2, 3, 4, and 6 said that playing games was their favorite hobby. Informant 5 did not say that he loved gaming, but that he and his friends shared the same hobby. A hobby is a pleasant activity that can grow into a habit or routine. Based on some observations, the researchers know that every informant had a smartphone with gaming applications, which signifies that the informants have the supporting facilities for their hobby. A game is an activity that makes people feel happy and comforted [2]; therefore, it is undeniable that playing games can make someone eager to play regardless of the time of day. However, playing games every day can lead to addiction [26], [27]. In addition to characterizing games as hobbies, all informants had regularly played games for more than 6 months.

According to its definition, game addictions refer to people who meet the criteria of addiction for 6 months [4]. In addition, all informants usually played games for more than $3 \mathrm{~h}$ per day. Indeed, playing games is so fun that people can lose track of time while playing. However, playing games for more than $3 \mathrm{~h}$ per day can someone to become addicted [28]. Anggarani points out that game addiction is understood as persistence and continuous participation in a game for a long time [18]. In the current research, a triangulation method with the addiction scale showed that all informants experienced game addiction to a high degree $(100 \%)$.

Game addiction also caused the informants to skip their meals and urination and stay up late at night, so they experienced fatigue, dizziness, and a low ability to concentrate. This finding is suitable with research conducted by Van Den Eijnden et al. [29], which described the negative impacts of game disorder symptoms and social media use on teenagers. Fitria mentioned that there is a positive correlation between online gaming and sleeping pattern disorder [30]. Likewise, the current study found that the informants usually stayed up late at night when playing games. Sinanto and Djannah confirmed that game addiction causes the informants to neglect their physical health [15].

The informants also skipped their meals when playing for more than $3 \mathrm{~h}$ per day. This finding is similar to a study by Susanti et al. [31] in which a correlation was found between online games on smartphones and eating habits. Moreover, a study by Angkow et al. [32] proves that there is a significant correlation between eating patterns and gastric incidents. On the other hand, delaying urination also results in serious health problems. Sari [33] discovered a correlation between the habit of holding urination and urinary tract infections. Ghuman and Griffiths [34] stated that playing games have negative impacts such as health problems, and Novrialdy [35] explained that game addiction harms

Table 4: The interview results on the obstacles of restricting online gaming

\begin{tabular}{|c|c|c|c|c|c|}
\hline Informant 1 & Informant 2 & Informant 3 & Informant 4 & Informant 5 & Informant 6 \\
\hline $\begin{array}{l}\text { Friend's invitation, } \\
\text { boredom, fun, free } \\
\text { time, and self-control }\end{array}$ & $\begin{array}{l}\text { Friend's invitation, irresistible } \\
\text { fun of gaming, the e-sports } \\
\text { trend, target-oriented, } \\
\text { difficulty in changing habits, } \\
\text { and self-control }\end{array}$ & $\begin{array}{l}\text { Friend's invitation, the fun of } \\
\text { gaming, data or Wi-Fi availability, } \\
\text { the current trend of e-sports, } \\
\text { target-oriented in the game, and } \\
\text { difficulty in changing habits }\end{array}$ & $\begin{array}{l}\text { Surrounded by game lovers, self-control, } \\
\text { always focus on the game, friend's } \\
\text { invitation, boredom, difficulty in changing } \\
\text { habits, irresistible fun of gaming, keep } \\
\text { gaming despite feeling sick }\end{array}$ & $\begin{array}{l}\text { Friend's invitation, irresistible } \\
\text { fun of gaming, problems of } \\
\text { self-control, temptation on } \\
\text { watching people playing games, } \\
\text { losing track of time }\end{array}$ & $\begin{array}{l}\text { Dissatisfaction, } \\
\text { too detached to } \\
\text { gaming }\end{array}$ \\
\hline
\end{tabular}


teenagers. Conclusively, the informants who had game addiction were at risk of health problems.

The current study observed that the informants did not want to quit the game because they felt challenged, dissatisfied, and could not control themselves when playing even though they did not feel well. This data confirms the statement by the Ministry of Health on game addiction that explains how a game-addicted person will continue playing despite knowing its negative impacts [36]. According to Hussain and Griffiths [37], some people usually play games excessively to escape from their lives. An online game-addicted teenager is more interested in an online game than any other activity [38]. This notion is similar to Edrizal's [27] findings, which state that online game addictions have negative impacts, such as spending more time playing games on a computer or in the Internet cafe, so someone might skip studying or other activities that can harm their health. A study also discovered that when the behavior of playing online games is repeated and normalized, the dopaminergic pathways in the brain will be stronger and persist, thus causing addiction, which will then strengthen the reactive system and weaken the reflective system. This leads to the decline of cognitive abilities decline, making it difficult for individuals to control themselves [39]. This reflects the behavior of the informants who did not want to quit the game because they cannot demonstrate selfcontrol and keep themselves from playing.

Every informant was aware of the negative impacts of game addiction. Moreover, they had also experienced the effects of playing for long periods of time and understood the importance of time restriction when playing games regarding their health. Nevertheless, they found some problems in reducing their gaming hours because of friendship, gaming hobbies, and game addiction. Darmawan et al. observed that a friendship circle strongly influences one's behavior [40]. Although the informants already perceived the impacts of excessive gaming, they still had difficulties restricting themselves from gaming as they did not have a strong willingness to do so.

All informants are not yet ready to improve their behavior. According to the theory of the transtheoretical model, there are six stages of change: pre-contemplation, contemplation, preparation, action, maintenance, and termination. In this case, all informants are in the first stage since they did not have plans to start a healthy lifestyle soon (within 6 months) and probably do not realize the need to change [41]. The theory suggests that there should be some type of health education for the informants to help them in initiating healthy behaviors. Behavior is the result of experience and the process of interaction with the environment which is manifested in the form of knowledge, attitudes, and actions [42]. According to Trijayanti, knowledge will stimulate a person's thinking, which in turn motivates them to take action [43]. It implies that knowledge influences behavioral change. Another important aspect to consider is that when a game addict begins treatment, their well-being must be considered after the process as well [44] so that more severe mental illness will not infect them.

This study suggests that parents of adolescents could review the functions of the family in providing education, affection, and protection to teenagers. This includes providing rules or signs for making friends with peers. In addition, other related parties may also encourage the health promotion efforts for teenagers in understanding the importance of online game restrictions to help them find alternative hobbies or activities that have more positive effects.

\section{Conclusion}

The research found that the overall profile of the informants was male students aged between 21 and 24 years old who experienced a high level of game addiction. For these teenagers, the game was an entertaining activity that relieved stress and made them happy and that they played in their spare time, but that caused them to skip meals, delay urination, stay up late, and have trouble quitting. They did not want to restrict their gaming habits because of some obstacles, such as friend's invitations to play games, the irresistible fun of playing games, problems regarding self-control, the temptation of seeing other people playing games, boredom, and the current e-sports trend.

\section{Acknowledgments}

We are appreciative of the Universitas Ahmad Dahlan for funding this research and the informants who involved in this study.

\section{References}

1. World Health Organization. Sharpening the focus on gaming disorder. Bull World Health Organ. 2019;97(6):382-3. http://doi. org/10.2471/BLT.19.020619 PMid:31210674

2. Efendi A, Marnelly R. The impact of playstation game (PS) addiction among Riau university students. Online J Students Fac Soc Polit Sci Riau Univ. 2014;1(2):1-15. http://doi.org/10.1017/ CBO9781107415324.004

3. Masya $\mathrm{H}$, Candra DA. Factors affecting online game addiction disorder behavior in Class $X$ students at Madrasah Aliyah A Furqon Prabumulih. Guid Couns J. 2016;3(1):17 
4. Lemmens JS, Valkenburg PM, Peter J. Development and validation of a game addiction scale for adolescents. Med Psychol. 2009;12(1):77-95. http://doi.org/10.1080/15213260802669458

5. Young K. Cognitive behavior therapy with internet addicts: Treatment outcomes and implications. Cyberpsychol Behav. 2007;10(5):671-9. doi: http://doi.org/10.1089/cpb.2007.9971 PMid: 17927535

6. Syahran R. Ketergantungan online game dan penanganannya. J Psikol Pendidik Konseling. 2015;1(1):84-92. http://doi. org/10.26858/jpkk.v1i1.1537

7. World Health Organisation. Gaming Disorder. Geneva: World Health Organisation; 2018.

8. Newzoo. The Indonesian Gamer 2017; 2017.

9. Sari E. The role of assistance and budget impacts in the field of marine and fisheries on welfare conditions of fishermen community in ende district. J Ekon Mercu Buana. 2018;6(1):78102. http://doi.org/10.26486/jpsb.v6i1

10. Zhang $M X, W u$ AM. Effects of smartphone addiction on sleep quality among Chinese university students: The mediating role of self-regulation and bedtime procrastination Addict Behav. 2020;111:106552. http://doi.org/10.1016/j. addbeh.2020.106552

11. Shiue I. Self and environmental exposures to drinking, smoking, gambling or video game addiction are associated with adult hypertension, heart and cerebrovascular diseases, allergy, selfrated health and happiness: Japanese General Social Survey, 2010. Int J Cardiol. 2015;181:403-12. http://doi.org/10.1016/j. ijcard.2014.12.071

PMid:25555287

12. Mawo PR, Rante SD, Sasputra IN. Relationship between sleep quality and hemoglobin levels in undana faculty of medicine students. Cendana Med J. 2019;17(2):158-63.

13. Ayu L, Saragih S. Social interaction and self-concept with online game addiction in early adults. Pers Psikol Indones. 2016;5(2):167-73. http://doi.org/10.30996/persona.v5i02.734

14. Hakim S, Raj A. Dampak Kecanduan Internet (Internet Addiction) Pada Remaja. Vol. 1. In: Peran Psikologi Perkembangan dalam Penumbuhan Humanitas pada Era Digital; 2017. P. 280-4.

15. Sinanto Ra, Djannah SN. The health effects of game addiction on young gamers: A systematic review. VISIKES. 2020;19(2):410-9.

16. Bai FG. Perbedaan Tingkat Kecanduan Game online Pada Remaja Antargaya Pengasuhan; 2015.

17. Creswell JW. Penelitian Kualitatif and Desain Riset: Memilih di Antara Lima Pendekatan. $3^{\text {rd }}$ ed. Yogyakarta: Pustaka Pelajar; 2015.

18. Anggarani FK. Internet gaming disorder: Psychopathology of modern culture. Psychol Bull. 2015;23(1):1. doi: 10.22146/ bpsi.10572

19. Miswanto E, Armitasari A, Muhazir M. Online Game Addiction in terms of Gender Male and Female. In: Mengukuhkan Eksistensi Peran BK Pasca Pandemi Covid-19 di Berbagai Setting Pendidikan; 2020. p. 43-51.

20. ChenKH, Oliffe JL, KellyMT. Internetgaming disorder:Anemergent health issue for men. Am J Mens Health. 2018;12(4):1151-9. doi: http://doi.org/10.1177/1557988318766950 PMid:29606034

21. Hyun GJ, Han DH, Lee YS, Kang KD, Yoo SK, Chung US, et al. Risk factors associated with online game addiction: A hierarchical model. Comput Human Behav. 2015;48:706-13. http://doi.org/10.1016/j.chb.2015.02.008

22. Nagorsky E, Wiemeyer J. The structure of performance and training in esports. PLoS One. 2020;15(8):e0237584. http://doi. org/10.1371/journal.pone. 0237584

PMid:32841263
23. Adjie JM. Adolescent Reproductive Health in Social Aspects. Indonesian Pediactric Society; 2013.

24. Yosephine $Y$, Lesmana T. Parenting patterns and the tendency of online game addiction in late adolescents in Jakarta. Psibernetika. 2020;13(1):49-58. http://doi.org/10.30813/ psibernetika.v13i1.2272

25. Brand JE, Todhunter S, Jervis J. Digital Australia 2018 (DA18). Bond University; 2017

26. Pratama R, Widianti E, Hendrawati. Tingkat kecanduan game online pada mahasiswa fakultas keperawatan. JNC. 2020;3(2):110-8.

27. Edrizal. Pengaruh kecanduan siswa terhadap game online (studi tentang kebiasaan siswa bermainn game online) di SMP N 3 Teluk Kuantan. J PAJAR. 2018;2(6):1001. http://dx.doi. org/10.33578/pjr.v2i6.6543.

28. Laili FM, Nuryono W. Application of family counseling to reduce online game addiction in class Viii junior high school 21 surabaya. J BK. 2015;5(1):65-72.

29. Van Den Eijnden R, Koning I, Doornwaard S, Van Gurp F, Ter Bogt $T$. The impact of heavy and disordered use of games and social media on adolescents' psychological, social, and school functioning. J Behav Addict. 2018;7(3):697-706. http://doi. org/10.1556/2006.7.2018.65

PMid:30264607

30. Fitria R. Old games online games against student sleep pattern disorders. Real Nurs J. 2019;2(2):72. http://doi.org/10.32883/ rnj.v2i2.484

31. Susanti MM, Widodo WU, Safitri DI. Addiction relationship playing online games on smartphones (mobile online games) with the diet of elementary school children grades 5 and 6 in SD Negeri 4 Purwodadi. Light Shine Ners World. 2018;3(2):122. http://doi.org/10.35720/tscners.v3i2.122

32. Angkow J, Robot F, Onibala F. Factors associated with gastritis in the work area of the Manado city shoulder health center. J Nurs UNSRAT. 2014;2(2).

33. Sari RP. Urinary tract infection (UTI) and risk factors affecting female employees at the university of Lampung event numbers urinary tract infection (Uti) and risk factors that affecting on female employees in university of Lampung. Majority. 2018;7(3):115-20.

34. Ghuman D, Griffiths MD. A cross-genre study of online gaming: Player demographics, motivation for play, and social interactions among players. Int J Cyber Behav Psychol Learn. 2012;2(1):1329. http://doi.org/10.4018/ijcbpl.2012010102

35. Novrialdy E. Online game addiction in adolescents: Impact and prevention. Psychol Bull. 2019;27(2):148. http://doi. org/10.22146/buletinpsikologi.47402

36. Kemenkes. Kecanduan Game Adalah Gangguan Perilaku; 2018.

37. Hussain Z, Griffiths MD. Excessive use of massively multi-player online role-playing games: A pilot study. Int J Ment Health Addict. 2009;7(4):563-71. http://doi.org/10.1007/s11469-009-9202-8

38. Jannah $\mathrm{N}$, Mudjiran M, Nirwana $\mathrm{H}$. The relationship between game addiction and student motivation and its implications for guidance and counseling. Counselor. 2015;4(4):200. http://doi. org/10.24036/02015446473-0-00

39. Lutfiwati S. Memahami kecanduan game online melalui pendekatan neurobiologi. Anfusina J Psychol. 2018;1(1):1-16. https://doi.org/10.24042/ajp.v1i1.3643

40. Darmawan T, Nurwati N, Gutama AS. The effect of peer interaction on juvenile delinquency in sman 1 Cicalengka, Cicalengka district, Bandung Regency. Res Community Serv Proc. 2016;3(1):1-4. http://doi.org/10.24198/jppm.v3i1.13624

41. Kholid A. Promosi Kesehatan Dengan Pendekatan Teori Perilaku, Media, dan Aplikasinya. $1^{\text {st }}$ ed. Depok: Rajawali Pers; 2017. 
42. Induniasih, Ratna W. Promosi Kesehatan: Pendidikan Kesehatan Dalam Keperawatan, Cetakan I. Yogyakarta: Pustaka Baru Press; 2017.

43. Trijayanti DA. Perilaku tentang cuci tangan pakai sabun di madrasah ibtidaiyah taswirul afkar. J PROMKES. 2019;7(1):46. doi: http://doi.org/10.20473/jpk.v7.i1.2019.46-55

44. Widodo A, Supratman S. The different mental health patient quality of life during shackling, treatment, and post treatment. Epidemiol Soc Health Rev. 2020;2(2):45. http://doi. org/10.26555/eshr.v2i2.2164 